\title{
Subduction fluxes through geologic time
}

\author{
John Ludden \\ British Geological Survey, Keyworth, Nottingham NG12 5GG, United Kingdom \\ E-mail address: jludden@bgs.ac.uk
}

\begin{abstract}
Much of my research career has been spent working both on modern oceanic volcanic systems and at the same time looking at their Archaean counterparts. Many authors have attempted to make inferences on early Earth models based on modern processes which can be increasingly well constrained. In this short review I show how we are beginning to understand and quantify inputs to modern subduction systems and I pose some questions as to how these processes may have affected Earth's evolution in its distant past.

Geochemical models have convincingly demonstrated that sediment and altered oceanic crust must be recycled into the mantle through subduction zones. These 'subduction factories' use these components, along with molten mantle, to create arc magmas. The 'residue' from this process is recycled into the mantle and has a modified chemical and mineralogical composition. The altered oceanic crust input function in the current plate tectonic cycle seems to be relatively constant in composition, but the chemical compositions of the sediment fluxes into subduction zones vary widely and control many of the end-member compositions of arc magmas. They must also control the compositions of fluids and gases derived from these magmas and ultimately ore-deposition and atmospheric fluxes associated with arc volcanoes.
\end{abstract}

There is relatively strong evidence for subduction processes for at least the past 3.5 Ma and some would argue that exogenic components have been recycled into the mantle since at least 4.3 Ma. How might the subduction fluxes have changed through time, and how might they have influenced crust, ocean and atmospheric compositions? Can different ore regimes in temporal and spatial distribution on Earth be related to the change in inputs and residues from the subduction factory through time?

\section{Introduction}


It is generally accepted that the subduction zones of the planet are the main focus of recycling material back into the mantle and also of stabilization and creation of continental crust (e.g., Armstrong, 1968, 1991; VonHuene and Scholl, 1991; Plank and Langmuir, 1998). Geochemical tracers of various kinds have been used to model this process through the history of Earth. There is still considerable discussion on when plate tectonics started. What was recycled? How much crust was created and destroyed at different time intervals throughout the Earth? How may this have influenced the composition of the crust, mantle, ocean, and atmosphere?

In this short paper I do not intend to answer all of these problems, but I will focus on how we are beginning to constrain and understand modern subduction cycles, and how some of the different input functions that we can now observe must have changed and most probably influenced key geochemical processes on Earth.

\subsection{Fluxes at subduction zones}

Figure 1 (Anbar and Rouxel, 2007) provides a schematic view of the sequence from the production of oceanic crust at ridges to its subduction in convergent margins. The ocean crust matures through cooling and interaction with sea-water and also through hydrothermal exchange with cooling magma bodies in the deep ocean crust. These processes change its composition and also the global composition of sea-water. It was recognized relatively early after the discovery of hydrothermal systems that the global balance of major elements such as Ca and $\mathrm{Mg}$ were controlled in part through hydrothermal alteration of oceanic crust (Mottl and Wheat, 1994).

Fig. 1. Inputs into the subduction factory from altered oceanic crust and entrained sediments. Adapted from Anbar and Rouxel (2007). 


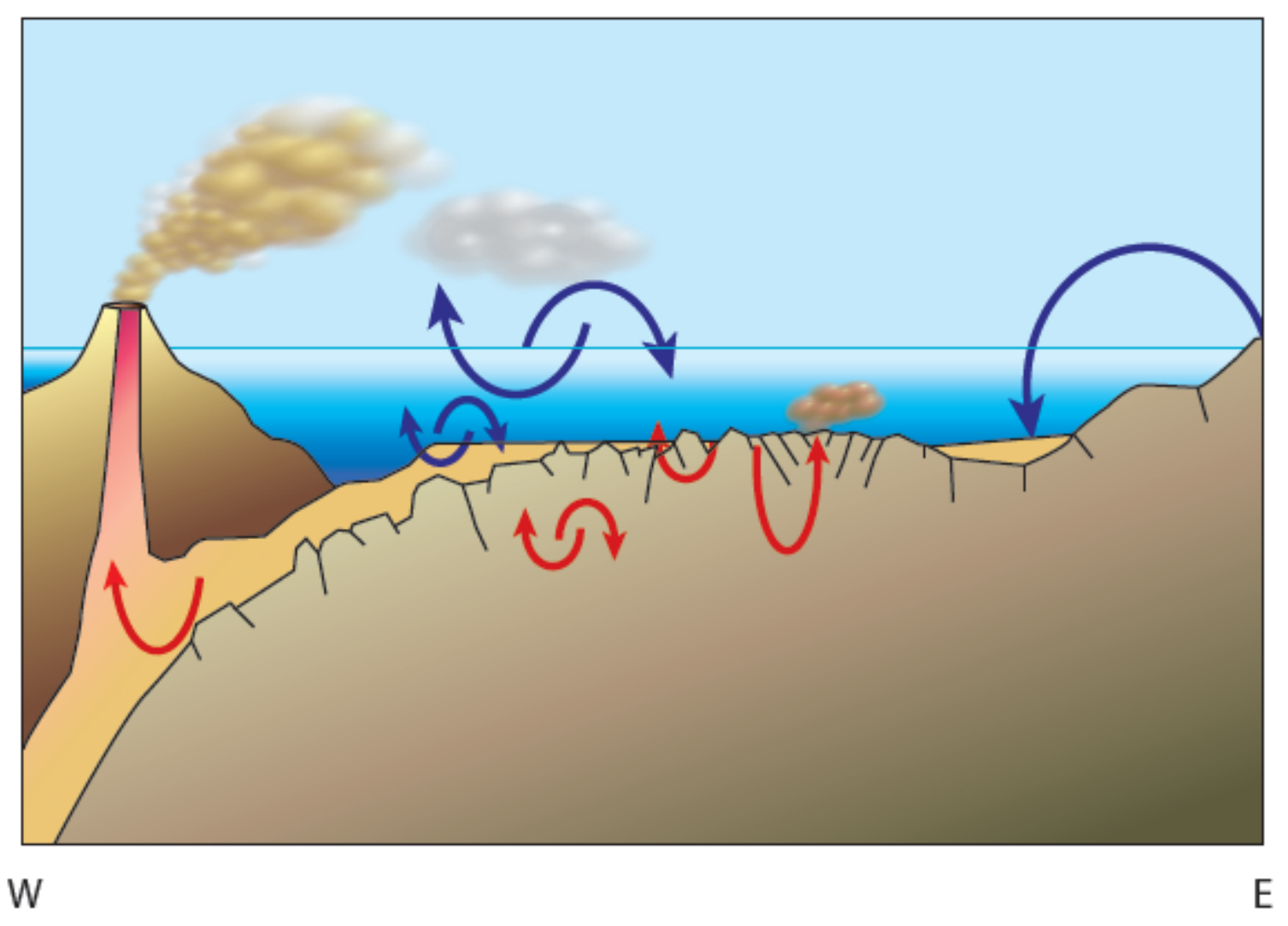

The carbon budget is also controlled in part by the exchange of warmed sea-water with oceanic crust (Alt and Teagle, 1999), as are some of the key trace elements (K, U, and $\mathrm{Pb}$ ) that control the isotopic evolution of the planet (Staudigel and Hart, 1983). Apart from the odd serendipitous discovery of hydrothermally altered crust exposed in fractures zones in the oceanic crust, the only systematic sampling of oceanic crust to study these budgets has been through oceanic drilling by ODP and IODP.

In addition to altered oceanic crust, the other important input flux to the subduction system is sediment that has accumulated on the crust since its creation at the ridge axis. As demonstrated in Fig. 1, this sediment is trapped in the subducting wedge and some of it contributes to the creation of the accretionary prism and is scraped off during subduction, as is often the case for the upper part of the oceanic basement (Kimura and Ludden, 1995). Nonetheless, the composition of volcanic rocks extruded in volcanic arc systems clearly indicates that some of these sediments are entrained into the mantle and participate in the melting process that produces magmas in arcs (Plank and Langmuir, 1993). Models defining the amount of sediment involved in this process vary widely, but even conservative estimates may place $2 \%$ subducted sediment as a component in magmas and, depending on the composition of the sediment, this may strongly influence the magma composition. Whole mantle models using tracers sensitive to sediment addition, such as Hf isotopes (Blichert-Toft et al., 1999) also indicate that sediment is 
mixed back into the mantle during this process.

The sediments that can be introduced into the 'subduction factory', as it has been termed, vary widely in composition, from purely ocean or hydrothermal derived chemical or organic precipitates, through volcanogenic sediment sloughed off volcanic seamounts, volcanic ash from the subduction systems themselves, to water- and airborne terrigenous sediments. The only means of defining these sedimentary assemblages has been through drilling type sections close to subduction zones, and IODP has done this on a number of occasions. In some cases sampling was done with the expressed aim of characterizing the full subduction assemblage (Legs 123, 185). In Leg 185, we went as far as developing composite samples that can be used as a reference for modeling the fluxes in the subduction factory (Kelley et al., 2005).

Two relatively simple models indicate the importance of this process in the control of magma and mantle compositions:

\subsubsection{The U/Pb ratio of altered recycled basaltic oceanic crust}

Figure 2a (Kelley et al., 2003) shows that as the oceanic crust ages and interacts with sea-water and is oxidized, its $U$ content increases. The original composition of $U$ in the crust is about $0.2 \mathrm{ppm}$ and with oxidation increases can be greater than ten-fold. The enhanced values are located at the top of the section where oxidation is most pervasive as well as in localized alteration zones through the crust. One of the challenges is estimating the bulk composition of elements such as $U$ in the oceanic crust, and Kelley et al. (2005) have attempted this by using gamma logs and also discrete samples. Estimates of the altered crust are about $0.4 \mathrm{ppm}$ and unaltered glass at 0.08 $\mathrm{ppm}$. The $\mathrm{U} / \mathrm{Pb}$ ratio of altered crust is thus increased by alteration processes. As shown in Fig. $2 \mathrm{~b}, \mathrm{U}$ and $\mathrm{Pb}$ are lost at different stages in the subduction process due to difference in their partition coefficients. Interestingly, as modeled by Kelley et al. (2005), all of the lavas of the Honshu-Izu-Mariana system align along mixing lines which define a $\mathrm{Pb} / \mathrm{U}$ ratio of 30 and reflect an eight-fold enrichment of $\mathrm{Pb}$ over $\mathrm{U}$ in the fluids derived from the subducted slab (Fig. 2b?). The residue is thus an altered oceanic crust which will transform to eclogite on, and sink into, the mantle and will have a very high $\mathrm{U} / \mathrm{Pb}$ ratio that through time will generate a highly radiogenic mantle component. This component was proposed by Hofman and White (1982) to be the end member for high U/Pb mantle sources (the HiMU source). The results from Kelley were the first to provide a firm estimate of the input function to the subduction zone.

Fig. 2. (a) Down-hole distribution of $U$ based on gamma log data and also from discrete sampled and composite mixed samples (from Kelley et al., 2003). (b) $\mathrm{Pb} / \mathrm{U}$ and $\mathrm{Th} / \mathrm{U}$ ratios in arc systems from the west Pacific illustrating control by altered crust derived fluids (from Kelley et al., 2005). (c) Modelled fluxes of $\mathrm{U}$ and $\mathrm{Pb}$ in the zone system indicating differential $\mathrm{U}$ and $\mathrm{Pb}$ loss. The heavy black line traces slab losses at preferred growth rates. Yellow zones 
indicate maximum possible losses (from Kelley et al., 2005). (

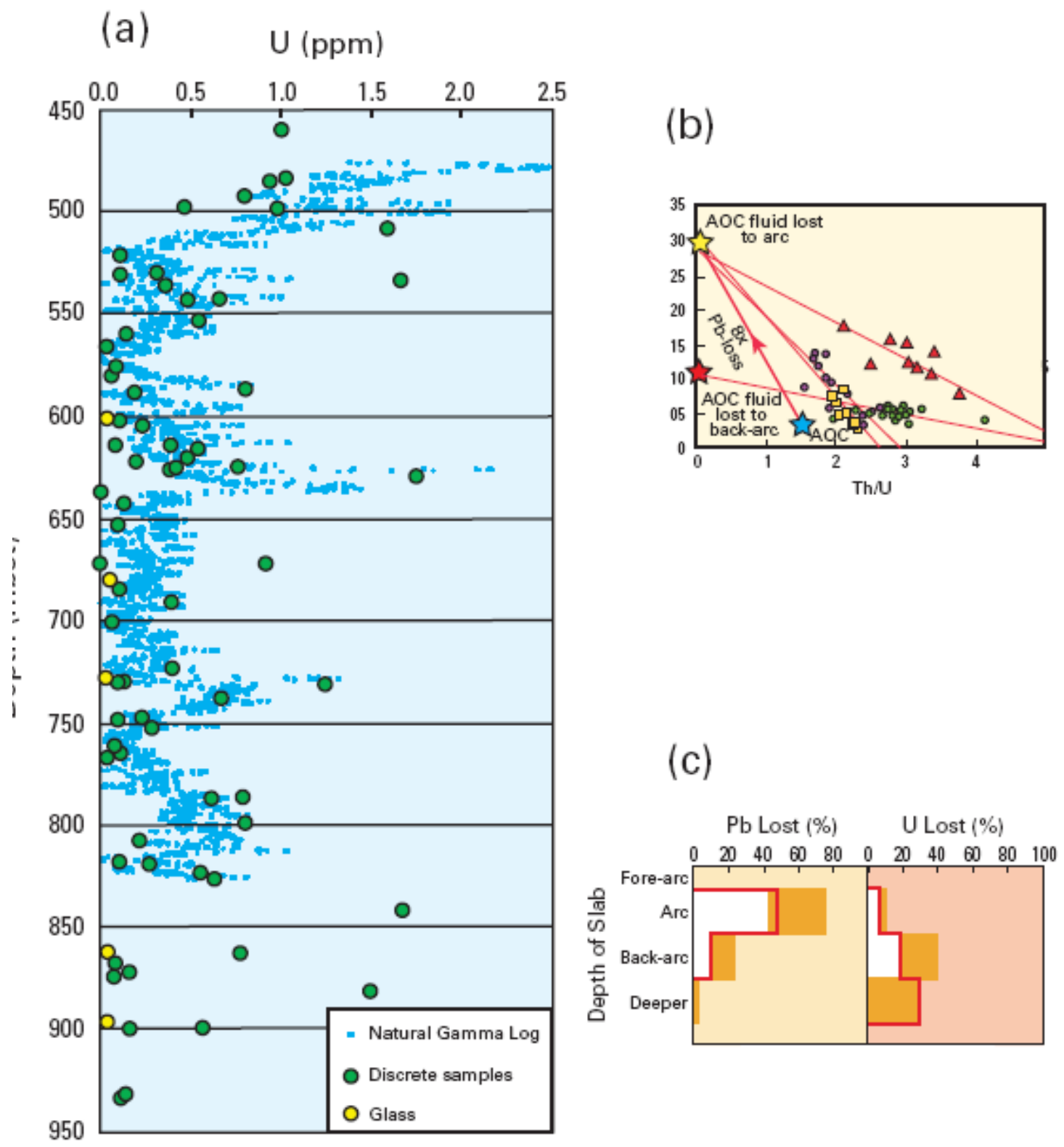

\subsubsection{Sediment input into the subduction system}

As demonstrated by Plank and Langmuir (1998) the composition of sediment input into subduction systems varies dramatically across the planet and as such different arc-systems are 'fed' by quite different sedimentary products with different geochemistry and mineralogy. One of the early demonstrations of the control of sedimentary 
input into arc systems was by White and Dupre (1986) where in the Lesser Antilles the influence of highly radiogenic Precambrian sedimentary rocks derived from the Archaean crust of northern South America diminishes from north to south up along the arc and the output from the volcanic systems varies congruently with the subducted sedimentary input. This demonstration was quantitative and it is only recently through drilling complete oceanic sections ocean-ward of arc=systems that we have been able to constrain the process a little better. As for the demonstration above for $\mathrm{U} / \mathrm{Pb}$ in altered oceanic crust, the first quantitative attempts to measure fluxes were the objective of ODP Leg 185 which drilled a series of holes ocean-ward of the Izu-Mariana arc (Ludden et al., 2006).

Fig. 3. (a) Th/La ratios of sediments from three West Pacific locations ocean-ward of the Honshu-Izu-Mariana arc system. (b) Mixing trends between mantle sources and subducted sediments for the Honshu-Izu-Mariana system (from Plank et al., 2007). 
(a)

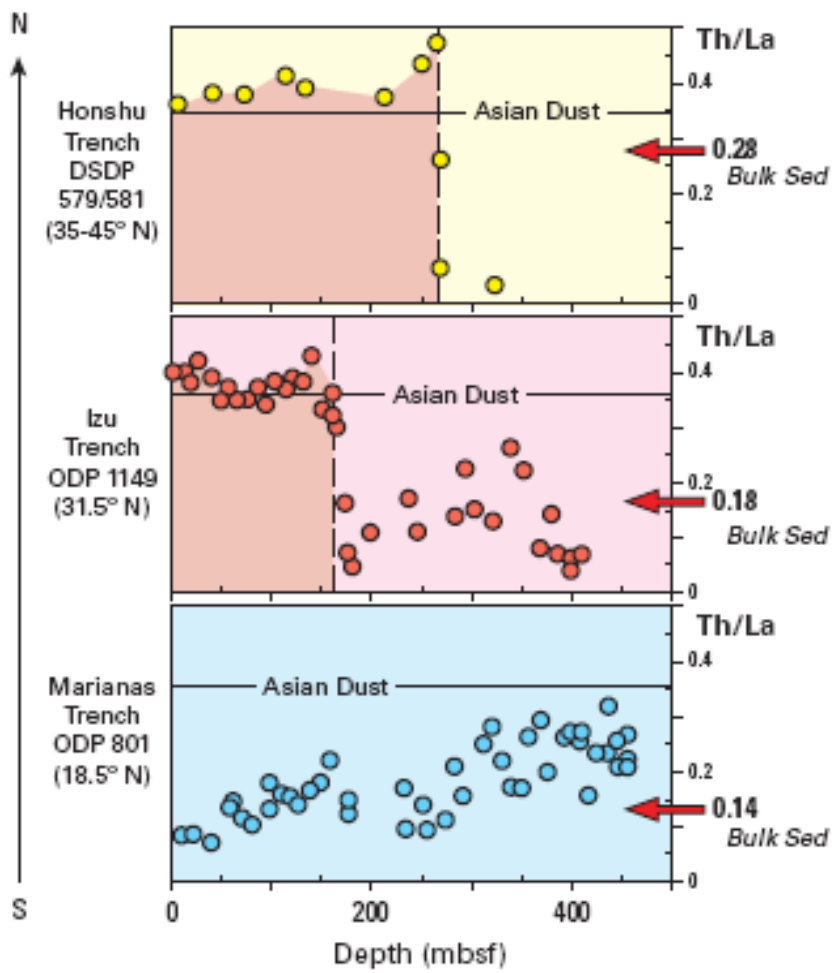

(b)

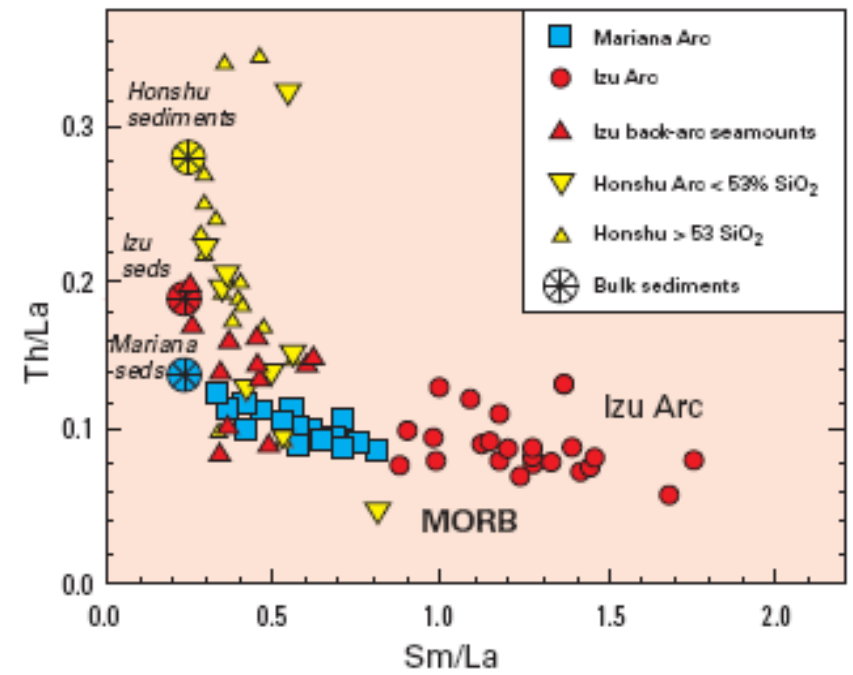


From north to south, from Honshu, through the Izu Bonnin Arc to the Marianas, the sedimentary assemblage is defined broadly by three components, each having a range in compositions: terrigenous components (wind derived, carried by ocean currents, etc.); authigenic sediments from the oceans (chemical and biological sediments); volcanogenic sediments derived locally from the arc, but also from volcanic seamounts on the oceanic plate. The proportions of these sediments vary along the arc and reflect different wind conditions (continental detritus blown in from Asia), different authigenic components (controlled by water depth, composition, compensation depths, hydrothermal sources, etc.) and also volcanogenic inputs from intra-plate volcanoes and also from the arcs themselves.

Figure 3a is taken from Plank et al. (2007). It defines the Th/La ratio in sediments in three ocean floor sections for three arcs in the West Pacific. The compositions of the volcanic products in the arcs (Fig. 3b) show well defined mixing trends from the mantle source to the sediment input composition in each arc. Honshu is the closest to the Asian dust input and thus has the highest Th/La ratio while the Mariana arc is dominated by sediments derived from volcanogenic components with a bulk composition near to that of the mantle.

These results for the West Pacific arc confirm the early inferences by White and Dupre, (1986) for the Antilles arc but allow geochemists to begin to better quantify the inputs to the subduction systems.

Over the past 10 years geochemists have thus started to place quantitative constraints on processes in arc systems. This is largely due to higher quality trace element geochemistry, but also a better understandings of partition coefficients for key elements (Hawkesworth et al., 1997) and also phase transitions during subduction processes. Furthermore, geophysicists are able to provide much better images of oceanic plates in the subduction system (Abers et al., 2006), allowing geologists to tie together structural, thermal, and chemical regimes in the subduction system.

How may these processes have worked in the earliest periods of Earth's evolution?

\section{Subduction zones in the early Earth}

I do not intend to cover all of the discussion on how and when subduction started on the Earth. There have been numerous articles written on the subject and academics will continue to fill journal pages with arguments on the subject. Suffice it to say that the results of the Canadian LITHOPROBE project have provided convincing arguments for subduction related processes and images of potential fossil subduction systems potentially as old as $3600 \mathrm{Ma}$ (Cook et al., 1998), but certainly well and truly active by about $3000 \mathrm{Ma}$ (Kimura et al, 1993). Figure 4 shows a seismic reflection image which has been interpreted as a fossil subduction zone. In this zone, Archaean greenstone assemblages (volcanic and sedimentary rocks) are thrust subducted below a plutonic complex - the 
Opatica plutonic complex, which can be traced across the Superior Province of Canada and reflects an ancient subduction system that was active at about 2800 Ma to 2700 Ma (Ludden and Hynes, 2000).

Fig. 4. A seismic reflection image which has been interpreted as an Archaean fossil subduction zone. Modified from Calvert et al. (1995).

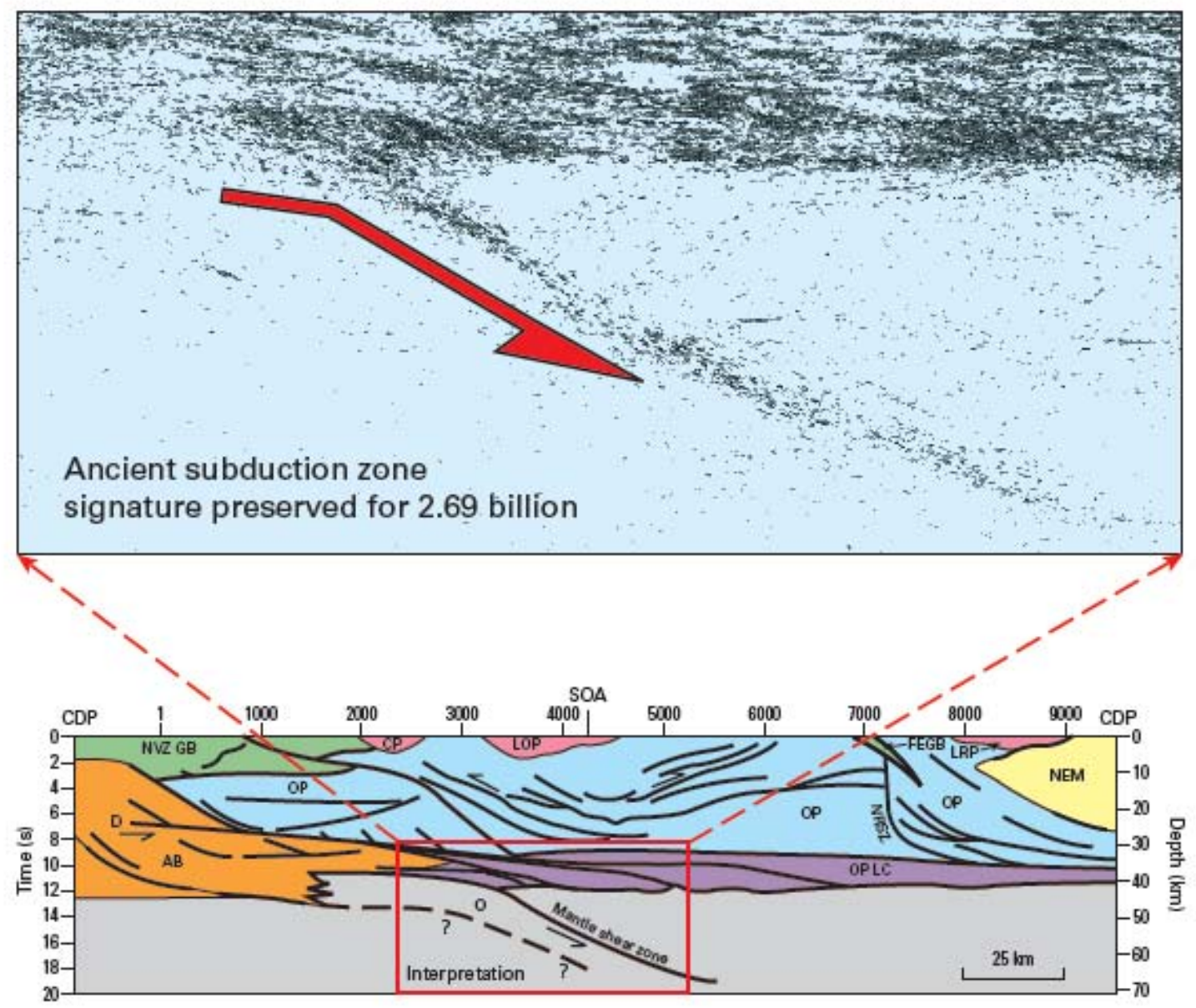

Geochemical and mineralogical data has been obtained from some of the oldest preserved minerals on Earth. Zircons preserved in younger sediments have been dated from as early as $4.3 \mathrm{Ga}$ (Harrison et al., 2005) and show characteristics which indicate an exogenic origin prior to their inclusion in Hadean plutonic rocks. Thus, there is relatively good evidence that sediments and altered materials from the surface of the Earth may have been recycled into the mantle since $4000 \mathrm{Ma}$ and perhaps before.

What was the chemistry of the altered oceanic crust and sediments that was subducted? How might this have 
reacted in the subduction zone? What would the consequences be for the mantle, arc volcanoes, and the atmosphere and oceans?

\section{How the geochemical recycling process may have changed through time}

Altered oceanic crust and the sediments carried into the subduction factory strongly influence numerous geochemical processes on Earth. I have addressed above some of the questions as to when did we start recycling altered oceanic crust and sediment into the mantle by subduction. Below, I speculate on some consequences of changing subduction regimes through time. There are numerous examples, some are highly speculative, but there is a renewed interest in early Earth processes due to our abilities to apply new geochemical tracers to the early Earth (Anbar and Rouxel, 2007) and I hope we will soon be able to apply firm constraints to some of the speculations below.

Some authors (Francis et al., 1999) would argue that basaltic crust was richer in iron in the early Earth. This could be due to a less oxidized mantle source which had yet to be oxidized by extensive subduction of volatiles back into the mantle. It could also be because the mantle itself generated more Fe-rich magmas from a mantle source that was different from that now forming at mid-ocean ridge axes.

High-Fe basalt mixed back into the mantle in the early Earth may now provide the source for some mantle plume magmas that are also rich in iron, and may not have a peridotitic mantle source, but rather a pyroxene dominated mantle source (Francis, 1995).

Although most arc-related magmas seem to be related to devolatilisation of the subducting plate, it is possible that the basaltic plate itself melts to generate andesitic magmas. Certain authors argue that adakite magma is formed this way in hot subduction zones in the modern Earth (Martin et al., 2005) and also argue that basaltic plate melting would have predominated in subduction processes in the early Earth, generating andesite, rather than basalt, as is the case in most modern subduction systems (Martin, 1987). This may be why the composition of andesite-dacite systems in the Archaean have high LREE/HREE ratios because the REE would have been fractionated by garnetrich eclogitic residues. The average composition of the crust generated in Archaean subduction systems may have been generally more andesitic (Rudnick and Gao, 2003)

Oxidized upper oceanic crust in the early Earth may not have been enriched in $\mathrm{U}$ and $\mathrm{K}$, as is the case now, and these elements may have had completely different controls in early Earth mantle processes. Uranium was not released from the crust until the Mesoproterozoic oxidation and the complete crust-mantle cycle of $U$ would have been different to that after the Neoproterozoic. High $\mathrm{U} / \mathrm{Pb}$ mantle sources may not have been formed until the Proterozoic. Indeed, they may have been formed preferentially in the Proterozoic when large quantities of Fe, $U$, and 
other elements susceptible to oxidation (e.g., molybdenum-Anbar and Rouxel, 2007) were sequestered on the ocean floor and thus made available for input to the subduction factories of the Proterozoic.

Base metal ore deposits do not seem to differ greatly in the mid- and late-Archaean from those now being formed in arc and ocean floor systems. The process of hot sea-water interaction with basaltic crust may not have changed dramatically through time, but the trace elements often associated with these deposits and often focused in subduction related ore-systems ( $\mathrm{Au}, \mathrm{Pb}, \mathrm{Mo}$, Sn, etc.) must have been influenced by the volatile fluxes in subduction systems. These must have been subject to different source compositions in the dewatering oceanic crust and sediments. One cannot help but imagine that the Proterozoic and Phanerozoic regions with high metal concentrations - the Proterozoic metal provinces, the west Pacific high-Au regions, the Bathurst Au camp - are related to inherited concentration processes in subduction systems that are atypical.

Carbonate fluxes into subduction systems must be related to precipitation processes on the sea-floor. We know, as shown in this article, that latitude influences carbonate accumulation on the sea-floor. Carbonate fluxes in the early Earth are related to abiotic carbonate fluxes, probably linked to metamorphic fluxes in the continental and ocean crust (Groves et al., 1988).

Phosphate and REE budgets in subduction zones now appear to be controlled by pelagic sediments deposited slowly on the sea-floor and taken into the subduction zones. Is the phosphorous budget of the mantle controlled in some way through subduction? Are some of the extreme magmas from the mantle, such as carbonatites, related to calcite and phosphorous injected back into the mantle - C and P that would relate to biological activity and reappear at the Earth's surface in magmatic systems?

Carbonate deposition predominates in cold water oceans. Plate configurations in which generally east-west subduction systems in cooler oceans, rather than longitudinal systems in temperate oceans, may result in a significant increase of the $\mathrm{CO}_{2}$ flux into the subduction system and thus more $\mathrm{CO}_{2}$ feed-back to the atmosphere and associated consequences for global change. This paper probably does not have a clear place in a journal such as Applied Geochemistry. It was solicited as part of a series of papers presented by the past presidents of the IAGC. Applied Geochemistry and the IAGC have developed a strong symbiotic relationship. This paper not only spreads across the bounds of geochemistry, it also covers Earth's history and the range in processes in the subduction system. It is impossible in a short paper to do justice to the problem. Suffice it to say that some of the geochemical fluxes of the Earth have important applied consequences and these are commonly not analyzed in the specialist literature. The changing oxidation state of the planet and the associated sediment flux to the sea-floor and into the subduction system, and ultimately the deep mantle, must have played a major role on chalcophile element fluxes and in ore deposit generation associated with subduction zone magmas. The U-cycle from the Neoproterozoic onward must have a control in subduction and erosion processes. The carbonate flux into subduction zones since the 
Paleozoic, and before, must depend on the global orientation of the subduction systems relative to the North and South Pole and hence the amount of carbonate precipitated on the sea-floor. The carbonate soaked up by ocean crust must also provide a strong constraint on the process of carbon capture and sequestration in minerals.

Although there are no new data in this paper, I hope the combination of geoscience subject matter has provided the reader with a 'few things to scratch their head over' and some of the implications for applied geochemistry are apparent.

\section{Acknowledgements}

I have worked with many scientists on the broad subjects outlined above, I thank them all. In particular, I cite Don Francis (McGill University, Canada) and Terry Plank (LDEO, Columbia University) who influenced much of my thinking and the LITHOPROBE and ODP projects which have underpinned a lot of the work outlined above. I thank IAGC for the opportunity to present this paper.

\section{References}

Abers, G.A., van Keken, P.E., Kneller, E.A., Ferris, A., Stachnik, J.C., 2006. The thermal structure of subduction zones constrained by seismic imaging: Implications for slab dehydration and wedge flow. Earth Planet. Sci. Lett. 241, 387-397.

Alt, J.C.I.; Teagle, D.A.H., 1999. The uptake of carbon during alteration of ocean crust: Mineralogy and chemistry. Geochim. Cosmochim. Acta 63, 1527-1535.

Anbar, A.D., Rouxel, O., 2007. Metal stable isotopes. In Paleoceanography. Ann. Rev. Earth Planet. Sci. 35,717-46.

Armstrong, R.L., 1968. A model for the evolution of strontium and lead isotopes in a dynamic. Earth Rev. Geophysics 6, 175-199.

Armstrong, R.L., 1991. The persistent myth of crustal growth. Aust. J. Earth Sci. 38, 613-630.

Blichert-Toft, J., Frey, F.A., Albarède, F., 1999. Hf isotope evidence for pelagic sediments in the source of Hawaiian basalts. Science, 285, no. 5429, 879-882.

Calvert, A.J., Sawyer, E.W., Davis, W.J., Ludden, J.N., 1995. Archaean subduction inferred from seismic images of 
a mantle suture in the Superior Province. Nature 375, 670-674.

Cook, F.A., van der Velden, A.J., Hall, K.W., Roberts, B.J., 1998. Frozen subduction in Canada’s Northwest Territories: Lithoprobe deep lithospheric reflection profiling of the western Canadian Shield. Tectonics 18, p. 1-24

Francis, D., Ludden, J., Johnston, R., Davis, W., 1999. Picrite evidence for more Fe in Archean mantle reservoirs. Earth Planet. Sci. Lett. 167, 197-213.

Francis, D., 1995. Implication of picritic lavas for the mantle sources of terrestrial volcanism. Lithos 34, 89-105.

Groves, D.I., Golding, S.D., Rock, N.M.S., Barley, M.E., McNaughton, N.J., 1988. Archaean carbon reservoirs and their relevance to the fluid source for gold deposits. Nature 331, 254-257.

Harrison, T.M., Blichert-Toft, J., Müller, W., Albarede, F., Holden, P., Mojzsis, S.J., 2005. Heterogeneous Hadean hafnium: Evidence of continental crust at 4.4 to 4.5 Ga. Science 310, 1947-1950.

Hawkesworth, C.J., Turner, S.P., McDermott, F., Peate, D.W.P., van Calsteren, P., 1997. U-Th isotopes in arc magmas: Implications for element transfer from the subducted crust. Science 276, 551-555.

Kelley, K.A., Plank, T., Farr, L., Ludden, J.N., 2005. Subduction cycling of U, Th, and Pb. Earth Planet. Sci. Lett. 234, 369-383.

Kelley, K.A., Plank, T., Ludden, J.N., Staudigal, H., 2003. The composition of altered oceanic crust at ODP Sites 801 and 1149. Geochem. Geophys. Geosyst. 4(6), doi: 10.1029/2002GC000435.

Kimura, G., Ludden, J., 1995. Peeling oceanic-crust in subduction zones. Geology 23, 217-220.

Kimura, G., Ludden, J.N., Desrochers, J.P., 1993. A model of ocean-crust accretion for the Superior Province, Canada. Lithos 30, 337-355.

Ludden, J.N., Plank, T., Larson, R.L., Escutia, C., 2006. Leg 185 synthesis: Sampling the oldest crust in the ocean basins to understand Earth's geodynamic and geochemical fluxes [online]. Proc. Ocean Drill. Program Sci. Results 185, 35 pp. (available at http://www-odp.tamu.edu/ publications/1 85 SR).

Ludden, J., Hynes, A., 2000. The Abitibi-Grenville Lithoprobe project: Two billion years of crust formation and recycling in the Precambrian Shield of Canada. Abitibi-Grenville Lithoprobe, Synthesis Volume. Can. J. Earth Sci. 
37, 459-476.

Martin, H., Smithies, R.H., Rapp, R., Moyen, J.-F., Champion, D., 2005. An overview of adakite, tonalitetrondhjemite-granodiorite (TTG), and sanukitoid: relationships and some implications for crustal evolution. Lithos 79, 1-24.

Martin, H., 1987. Petrogenesis of Archean trondhjemites, tonalites, and granodiorites from eastern Finland: Major and trace element geochemistry. J. Petrol. 28, 921-953.

Mottl, M.J., Wheat, C.G., 1994. Hydrothermal circulation through mid-ocean ridge flanks: Fluxes of heat and magnesium. Geochim. Cosmochim. Acta 58, 2225-2237.

Hofmann, A.W., White, W.M., 1982. Mantle plumes from ancient oceanic crust. Earth Planet. Sci. Lett. 57, 421436.

Plank, T., Kelley, K.A., Murray, R.W., Stern, L.Q., 2007. Chemical composition of sediments subducting at the Izu-Bonin trench. Geochem. Geophys. Geosyst. 8, Q04I 16, doi: 10.1 029/2006GC00 1444.

Plank, T., Langmuir, C.H., 1998. The chemical composition of subducting sediment: Implications for the crust and mantle. Chem. Geol. 145, 325-394.

Plank, T., Langmuir, C.H., 1993. Tracing trace elements from sediment input to volcanic output at subduction zones. Nature 362, 739-743

Rudnick, R.L., Gao, S., 2003. The composition of the continental crust, pp. 1-64. In The Crust (ed. R.L. Rudnick) Vol. 3, Treatise on Geochemistry (eds. H.D. Holland and K.K. Turekian), Elsevier-Pergamon, Oxford.

Staudigel, H., Hart, S.R., 1983. Alteration of basaltic glass: Mechanisms and significance for the oceanic crustseawater budget. Geochim. Cosmochim. Acta 47, 337-350, 441.

VonHuene, R., Scholl, D.W., 1991. Observations at convergent margins concerning sediment subduction, subduction erosion, and the growth of continental crust. Rev. Geophys. 29, 279-316.

White, W.M., Dupré, B., 1986. Sediment subduction and magma genesis in the Lesser Antilles: Isotopic and trace element constraints. J. Geophys. Res. 91, B6, 5927-5942. 